\title{
Assessing Suitable Habitats for Treefrog Species after Previous Declines in Costa Rica
}

\author{
Héctor Zumbado-Ulate ${ }^{1, *}$, Catherine L. Searle ${ }^{1} \mathbb{D}$, Gerardo Chaves ${ }^{2} \mathbb{D}$, Víctor Acosta-Chaves ${ }^{3,4}(\mathbb{D}$, \\ Alex Shepack ${ }^{5}$ (D), Stanley Salazar ${ }^{6}$ and Adrián García-Rodríguez ${ }^{7}$
}

check for updates

Citation: Zumbado-Ulate, H.; Searle, C.L.; Chaves, G.; Acosta-Chaves, V.;

Shepack, A.; Salazar, S.;

García-Rodríguez, A. Assessing

Suitable Habitats for Treefrog Species after Previous Declines in Costa Rica.

Diversity 2021, 13, 577. https:/ /

doi.org/10.3390/d13110577

Academic Editors: Miguel Ferrer and Steve A. Johnson

Received: 29 September 2021

Accepted: 9 November 2021

Published: 12 November 2021

Publisher's Note: MDPI stays neutral with regard to jurisdictional claims in published maps and institutional affiliations.

Copyright: (c) 2021 by the authors. Licensee MDPI, Basel, Switzerland. This article is an open access article distributed under the terms and conditions of the Creative Commons Attribution (CC BY) license (https:// creativecommons.org/licenses/by/ $4.0 /)$
1 Department of Biological Sciences, Purdue University, West Lafayette, IN 47907, USA; searlec@purdue.edu

2 CIBET (Museo de Zoología), Universidad de Costa Rica, 11501-2060 San Pedro, San José, Costa Rica; cachi13@gmail.com

3 Sede del Atlántico, Universidad de Costa Rica, Recinto de Paraíso, 30201 Paraíso, Cartago, Costa Rica; victor.acosta@ucr.ac.cr or vacosta@fieldstudies.org

4 School for Field Studies, Center for Sustainable Development Studies, 20501 Atenas, Alajuela, Costa Rica

5 Department of Biological Sciences, University of Notre Dame, South Bend, IN 46556, USA; ashepack@nd.edu

6 Dosel S.A Rain Forest Adventures, La Esperanza, 41003 Sarapiquí, Heredia, Costa Rica; stanleysalazar31@yahoo.com

7 BioInvasions, Global Change Macroecology-Group, Department of Botany and Biodiversity Research, University of Vienna, 1030 Vienna, Austria; adrian.garcia@univie.ac.at

* Correspondence: zumbadohector@gmail.com

Abstract: Treefrogs represent $22 \%$ of amphibian species in Costa Rica, but gaps in the knowledge about this group of amphibians can impede conservation efforts. In this study, we first updated the status of Costa Rican treefrogs and found that a total of $38 \%$ of treefrog species are threatened according to the most recent IUCN assessment in 2019. Additionally, 21\% of Costa Rican treefrog species have a high vulnerability to extinction according to environmental vulnerability scores. Then, we predicted the historical climatic suitability of eight target species that we expected to have exhibited changes in their ranges in the last 20 years. We assessed the location of new occurrence records since 2000 to identify recovery, range expansion, or previously underestimated ranges due to methodological limitations. We also estimated the area of each species' suitable habitat with two metrics: extent of suitable habitat $(\mathrm{ESH})$ and area of minimum convex polygon $\left(\mathrm{A}_{\mathrm{MCP}}\right)$. Six declined species exhibited recovery (i.e., new occurrences across historical range after 2000), with the widest recovery found in Agalychnis annae. We also found that Isthmohyla pseudopuma appears to have spread after the decline of sympatric species and that the range of I. sukia was originally underestimated due to inadequate detection. We found that the ESH was 32-49\% smaller than the $\mathrm{A}_{\mathrm{MCP}}$ for species that are slowly recovering; however, the ESH is similar or greater than the $\mathrm{A}_{\mathrm{MCP}}$ for species that are recovering in most of their ranges, as well as rare species with widespread ranges. Results of this work can be used to evaluate the risk of environmental threats and prioritize regions for conservation purposes.

Keywords: amphibians; Batrachochytrium dendrobatidis; diversity; remnant populations; threats; species distribution models

\section{Introduction}

Globally, amphibians are one of the most diverse groups of vertebrates, with nearly 8400 known species [1]; the tropics are where they have diversified more than many other region [2]. Given their nearly pan-global distribution, amphibians can provide relevant insights into the biology of communities and populations in a wide variety of environments, and in some scenarios, may act as useful indicators of ecosystem health [3]. In particular, treefrogs (i.e., all species contained within the families Hemiphractidae, Hylidae, and Phyllomedusidae) represent important functionaries in tropical streams and forest food webs across the globe [4]. Tadpoles and frogs move nutrients between aquatic and 
terrestrial systems and are important mediators of nitrogen cycling [5]. Treefrogs also occupy a multitude of habitats across their global range [6]. While many require or utilize arboreal habitats, almost all need some aquatic habitat for reproduction [7]. Treefrog species reproduce in streams, ponds, or even phytotelma in the canopy [8]. While most treefrogs have aquatic tadpoles, some-like those in the family Hemiphractidae-may reproduce without standing water by raising tadpoles in modified pouches on the female's back [9]. Treefrogs differ highly in terms of habitat preferences and breeding behavior, from species with protracted breeding, occurring throughout the year, to explosive breeders with punctuated reproductive events [9]. The biphasic lifestyle of most amphibians, but in particular, treefrogs, makes them especially susceptible to pressures from both the aquatic and terrestrial environments [10]. Like many amphibians, treefrogs are susceptible to several threats, such as habitat destruction, invasive species, climate change, and disease [11].

The surge in global amphibian declines, including many species of treefrogs, has been attributed to several causes, including disease [11]. Since the late 1970s, the spread of the amphibian chytrid fungus (Batrachochytrium dendrobatidis, hereafter ' $B d^{\prime}$ ) [12], the causal agent of chytridiomycosis [13], has been implicated in a growing number of extinctions and mass die-offs [14], especially stream-dwelling species from tropical highlands over $1000 \mathrm{~m}$ in elevation [15,16]. Recent estimates suggest that worldwide, more than 500 amphibian species have declined due to $B d$, with the majority of declines occurring in Central and South America [17], although this number is controversial [18]. In Mesoamerica, a wave of declines associated with epizootic outbreaks began in the late 1980s in southern Mexico and progressed throughout the early 2000s in eastern Panama $[19,20]$. Declines were first widely reported in Costa Rica in 1987, and the most well-known examples are represented by the still-enigmatic disappearance of the Monteverde golden toad (Incilius periglenes) [21,22] and the collapse of the entire amphibian community in Las Tablas [23] (Figure 1). In Costa Rica and throughout Central America, declines were most severe at mid and high elevations $(800-2500 \mathrm{~m})$ and along stream corridors [24,25]. This mountain habitat, well-suited for the growth and proliferation of $B d$ [15], was home to many treefrog species, particularly those in the genera Isthmohyla, Duellmanohyla, and Agalychnis [26]. Although Bd is now endemic across Mesoamerica [27-31] and numerous species have shown resilience [32], many areas and amphibian species have failed to recover after the introduction of $B d$ [26]. Other amphibian species appear to have spread during epizootics and enzootics phases of $B d$, potentially serving as a reservoir for the pathogen [33]. Due to their varying biology and histories with $B d$, treefrogs are a particularly informative group to evaluate the persistence and resilience of populations.

\section{History of Amphibian Monitoring in Costa Rica}

The knowledge of amphibian species compiled at the beginning of the twentieth century by Costa Rican enthusiasts (e.g., Anastasio Alfaro and Clodomiro Picado) and indigenous communities inspired taxonomists to study the amphibian diversity of Costa Rica [9]. First, Edward H. Taylor and colleagues studied amphibians across the Caribbean side, the Central Mountain range, and part of the Talamanca Mountain range [34]. Between the 1960s and the 1990s, Jay Savage and Douglas Robinson, with the assistance of their students, established two of the best biological collections of the Costa Rican herpetofauna $[9,35]$. Furthermore, William E. Duellman and Linda Trueb studied the diversity of treefrogs [7], and David Wake and his students described the diversity and abundance of salamanders across mountain ranges [36]. Additionally, Allan Pounds and Martha Crump documented the disappearance of the Monteverde golden toad and other amphibian species in the Tilarán Mountain range [21,22]. 


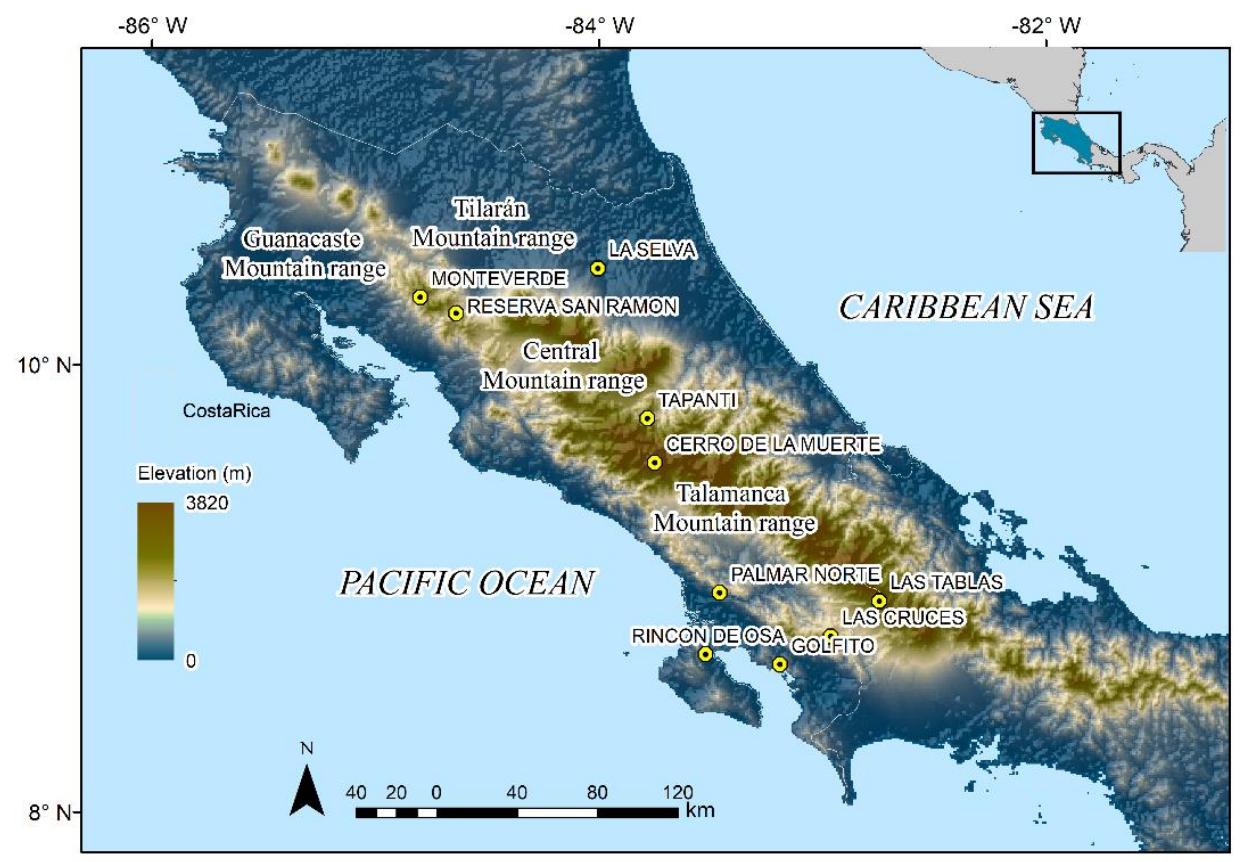

Figure 1. Map of Costa Rica showing ten historical localities (all caps) and main mountain ranges where long-term monitoring has been conducted even before amphibian declines occurred during the 1980 s and 1990s.

During the 1990s, Gerardo Chaves (GC) and Federico Bolaños from the Museo de Zoología, Universidad de Costa Rica (MZUCR), led monthly and annual surveys of declined amphibian species in Tapantí, Reserva de San Ramón, Cerro de la Muerte, Rincón de Osa, Golfito, Las Cruces, La Selva, and Palmar Norte (Figure 1). Furthermore, Karen Lips reported chytridiomycosis-driven declines across mountain areas of southern Costa Rica [23,37]. From 2000 to present times, GC and researchers associated with the MZUCR (including all the authors of this study and numerous colleagues) have rediscovered extant populations of declined amphibians across the country [38-41]. From 2006 to 2008, GC and Eduardo Boza participated in several surveys of the highlands of the Talamanca Mountain range with the UK's Darwin Initiative and Instituto Nacional de Biodiversidad of Costa Rica [42]. Similarly, GC and Mason Ryan carried out an intensive long-term monitoring program from 2000 to 2012 in 47 streams and tributaries across southern Costa Rica [39]. Most of the information collected since the 2000s has been used to quantify changes in amphibian diversity [43-46] and update the species' status in the most recent International Union of Conservation of Nature (IUCN) Red List Assessment [47].

Treefrogs, with 48 known species, represent $22 \%$ of amphibian species in Costa Rica [43]. In this study, we updated the conservation status of these 48 species using two metrics: the most recent IUCN Red List Assessment in Costa Rica and environmental vulnerability scores (EVS) [48]. We also generated predictions of the suitable habitat of eight target species of treefrogs to investigate three different patterns of increased detectability since 2000: (a) declined species that are now recovering in abundance, (b) common species that are increasing in range, and (c) data-deficient or uncommon species that have new information on occurrence and ecology. We compiled a robust dataset of occurrence points for our analyses using records from long-term field surveys conducted by the authors, peer-reviewed publications, biological collections, and citizen-science sources. Results from this work will help address information gaps in the current ranges and conservation status of Costa Rican treefrog species and may allow policymakers to better evaluate the risk of environmental threats and prioritize regions for conservation purposes. 


\section{Materials and Methods}

\subsection{Species Assessment}

We assessed all 48 known species of treefrogs included in the most recent official list of amphibian species in Costa Rica [43]. For every species, we found their updated status in Costa Rica [49] according to the most recent IUCN Red List Assessment conducted in 2019 [50] as follows: NA = "Not Applicable"; DD = "Data Deficient"; LC = "Least Concerned"; NT = "Near Threatened"; VU = "Vulnerable"; EN = "Endangered"; CR = "Critically Endangered"; EX = "Extinct in the wild" (for additional details see http: / / www.iucnredlist.org/ accessed on 1 September 2021). We also updated their EVS, a regional vulnerability index that classifies amphibians and reptiles into four levels of risk: "low vulnerability" (EVS of 3-9), "medium vulnerability" (EVS of 10-13), and "high vulnerability" (EVS of 14-17). High values of EVS often occur in range-restricted species, species that occur in a single-life zone, and species with a highly derived reproductive mode $[48,51]$.

\subsection{Study Species}

Based on the information provided by the historical monitoring in Costa Rica and the most recent IUCN Red List Assessment [47], we selected eight treefrog target species and estimated each species' climatic suitability based on new knowledge about their ecology, threats, and distribution (new observations in historical or current localities) [47].

Agalychnis annae (blue-sided treefrog; Figure 2a): This is a pond-breeding species that needs plants around small pools of water to reproduce [52]. It is endemic to Costa Rica and Panama [53]. The historic range in Costa Rica [5,7] includes the Central Valley and nearby areas, especially across the premontane region of the Central Mountain range and the premontane forest of the Pacific slope of the Talamanca Mountain range [9,54]. In Panama, it is only known in the Cerro Colorado region [55]. Because this species declined across the entire range during the 1980s and 1990s [52,56], including protected areas and other well-conserved lands, chytridiomycosis has been suggested as an important threat. However, remnant populations appear to tolerate infection by $B d$ [57]. The increase in vehicle traffic around coffee plantations where this species shelters is a major threat to this species.
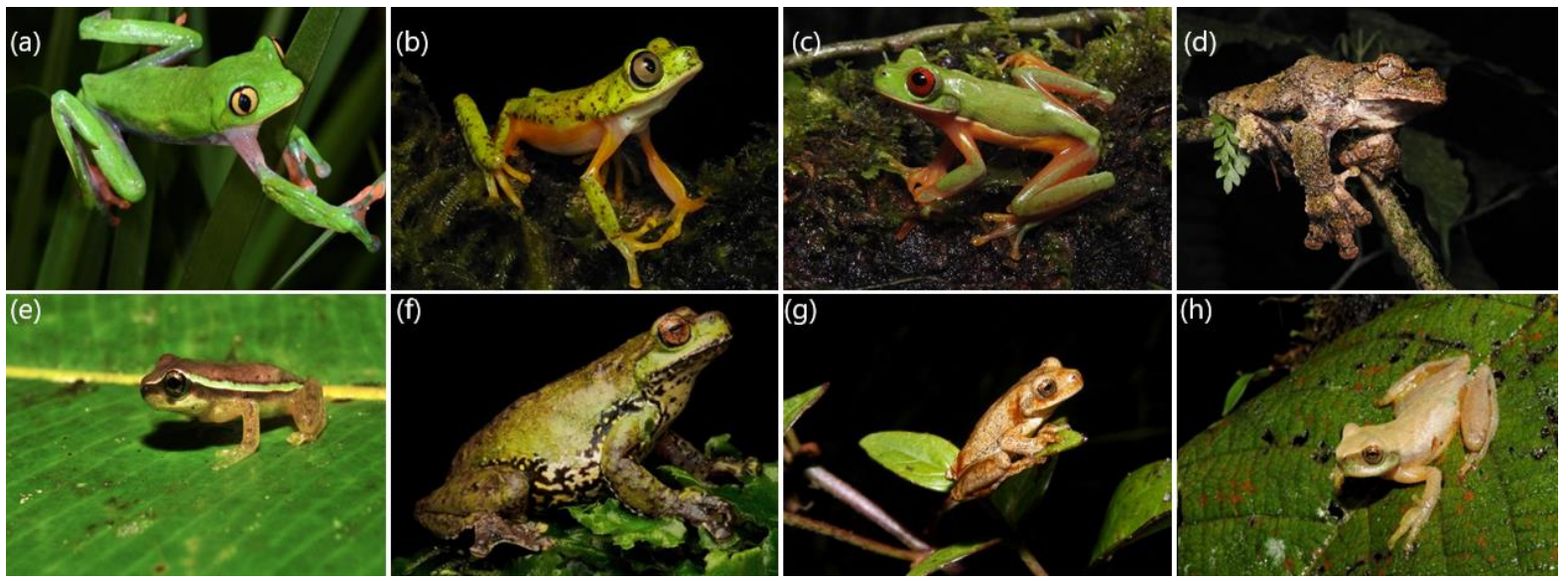

Figure 2. Study species: (a) blue-sided treefrog, Agalychnis annae (picture, Alex Shepack ); (b) lemur leaf frog, Agalychnis lemur (picture, Stanley Salazar); (c) Costa Rica brook frog, Duellmanohyla uranochroa (picture, Stanley Salazar); (d) Shaman fringe-limbed treefrog, Ecnomiohyla sukia (picture, Stanley Salazar); (e) narrow-lined treefrog, Isthmohyla angustilineata (picture, Fabio Hidalgo); (f) Pico Blanco treefrog, Isthmohyla pictipes (picture, Andrey Solís); (g) Gunther's Costa Rican treefrog, Isthmohyla pseudopuma (picture, Víctor Acosta-Chaves); (h) American cinchona plantation treefrog, Isthmohyla rivularis (picture, Víctor Acosta-Chaves). Reproduced with permission from Fabio Hidalgo and Andrey Solís. 
Agalychnis lemur (lemur leaf frog, Figure 2b): This is a small treefrog with a slim body and lacking finger and toe webs [9]. It is found from the Tilarán Mountain range in Costa Rica to the Colombian Chocó. The species declined across its entire range, particularly in Panama and the premontane and montane areas in Costa Rica [56]. Current known remnant populations in Costa Rica occur across the Caribbean slopes of the Talamanca Mountain range [58,59]. The major threats faced by this conspicuous frog include inbreeding, poaching, and chytridiomycosis [59].

Duellmanohyla uranochroa (Costa Rica brook frog; Figure 2c): It is a red-eye tree frog that lives in forests close to mountain streams [60]. Although males are easy to detect during the breeding season, the reproductive ecology of this species is poorly understood [9]. It is endemic to Costa Rica and Panama [61]. The species was known across the Tilarán, Central, and Talamanca mountain ranges, as well as Bocas del Toro in Panamá but declined across its range [9]. Chytridiomycosis has been suggested as a major threat; however, $B d$ has not yet been detected in this species [57].

Ecnomiohyla sukia (Shaman fringe-limbed treefrog; Figure 2d): It is a large, uncommon treefrog that inhabits water-filled cavities in the canopy of the mature, wet forest [62]. The females nest in water-filled cavities [62] and most likely exhibit parental care, similar to other species within the genus [7]. It is a Costa Rican endemic known to occur on the midlands of the Caribbean slopes in the foothills of the Tilarán, Central, and Talamanca mountain ranges [11]. It is also found in the northern Caribbean lowlands [45]. Major threats are unknown, but its dependence on old-growth forests suggests sensitivity to deforestation.

Isthmohyla angustilineata (narrow-lined treefrog; Figure 2e): This is a yellowishbrown and green nocturnal treefrog that lacks finger webs [7]. It usually breeds in small pools within the forest [9]. It is endemic to Costa Rica and Panama [63]. This species inhabits the Tilarán, Central, and Talamanca mountain ranges but rapidly declined across its range [51]. Major threats appear to be associated with chytridiomycosis and human development around remnant populations [47].

Isthmohyla pictipes (Pico Blanco treefrog; Figure 2f): It is a small montane treefrog that emits bright yellow fluorescence [64]. It is endemic to Costa Rica but possibly also found in Panama [65]. The species breeds in small streams in montane forests, where the males call from rocks or low vegetation [9]. This species occurs in the Central and Talamanca mountain ranges but declined across the entire range [7]. Chytridiomycosis has been suggested as a major threat [47].

Isthmohyla pseudopuma (Gunther's Costa Rican treefrog; Figure 2g): It is a yellowishbrown, middle-sized frog that lives in bromeliads and reproduces explosively in temporary ponds during the rainy season [7]. It is endemic to middle elevations in Costa Rica and Western Panama [66]. It is distributed along all cordilleras in the country [51], mainly in the Central Mountain range [9]. No major threats are known. This species appears to have become more common after the decline of sympatric species (G. Chaves, unpublished), and currently, it is one of the most common treefrog species in Costa Rica.

Isthmohyla rivularis (American cinchona plantation treefrog; Figure 2h): This is a $\tan$ treefrog that reproduces in small mountain streams, where the males call from the low vegetation year-round [7]. It is endemic to Costa Rica and Panama [67] and is found mainly in the Tilarán and Central mountain ranges but also occurs at the edges of the Talamanca Mountain range [9,51]. The major threats are habitat loss and disease [47].

\subsection{Datasets and Abiotic Data}

We compiled presence-only datasets for all eight focal species (Table S1) from five sources: (1) the herpetological database of the MZUCR (http:/ / museo.biologia.ucr.ac.cr/ accessed on 1 September 2021), (2) the Global Biodiversity Information Facility (GBIF; https:/ / www.gbif.org/ accessed on 1 September 2021) [68], (3) INaturalist (https:/ / www. inaturalist.org/ accessed on 1 September 2021), (4) field observations provided by the authors of this study and other researchers, and (5) peer-reviewed literature [58,64,69-73]. We 
cleaned data by checking for typos, cross-checking geographic coordinates, and removing unreferenced records, coordinates with a geographic inaccuracy $>1000 \mathrm{~m}$, and duplicates using the R packages 'scrubr' (https:/ / docs.ropensci.org/scrubr/ accessed on 1 September 2021) and 'CoordinateCleaner' [74]. To reduce the effect of spatial autocorrelation, we used the R package 'humboldt' [75] and excluded the occurrence points that were separated by distances $<2 \mathrm{~km}$.

We generated a raster stack with the 19 BIOCLIM variables [76] from WorldClim v2.1 [77] and 14 environmental variables from 'ENVIREM' [78], both at a spatial resolution of 30 arc-s. Following Title and Bemmels [78], we excluded the ENVIREM layers 'aridityIndexThornthwaite' (which is redundant with the 'climaticMoistureIndex') and 'monthCountByTemp10' (which is categorical). For climatic data extraction, we cropped the abiotic dataset with the R package 'raster' [79] using a bounding box encompassing the ranges of our study species $\left(6.5-11.5^{\circ} \mathrm{N}, 77-86.25^{\circ} \mathrm{W}\right)$. We used the function 'vifcor' in the $R$ package 'usdm' [80] to detect collinearity among predictors by quantifying the variance inflation factor (VIF). We selected the predictors with pairwise correlations $<0.6$ (Table S1). Our maps and geographic analyses were created with ArcGIS 10.7.1 (ESRI®Redlands, CA, USA) using the World Geodetic System datum (WGS84) and shapefiles from the Atlas Digital Costa Rica 2014 [81].

\subsection{Species-Range Predictions}

We used updated IUCN range polygons (available for download at http:/ / www. iucnredlist.org/ accessed on 1 September 2021) to calibrate our predictions of suitable habitats. The IUCN range polygons represent the area within the shortest continuous imaginary boundary that can be drawn to surround all the current known localities and the inferred occurrence and projected occurrence of a species [82,83]. For our focal species, we only considered the polygons corresponding to the extant and extinct ranges and excluded those that represent regions of uncertain presence. We adjusted our calibration areas by adding a buffer of $20 \mathrm{~km}$ to each polygon range. This calibration method allowed us to circle the occurrence points that were projected beyond range polygons and improve the accuracy of our predictions by including peripheral areas without extending to areas that are unlikely accessible for each species. For Agalychnis annae, Duellmanohyla uranochroa, Isthmohyla pictipes, and I. pseudopuma, we generated a calibration polygon that included the IUCN range polygons, the mountain areas of Costa Rica, associated foothills, and a buffer of $20 \mathrm{~km}$ ('Mountain_buffer'). Because of the scattered occurrence points of the endemic I. sukia, we used the extent of Costa Rica and a buffer of $20 \mathrm{~km}$ as the calibration area but cropped the North Pacific region of Costa Rica ('I_sukia_buffer'). Both shapefiles are available for download (see Data Availability Statement).

We generated predictions of the suitable habitat of the eight study species using the MaxEnt algorithm [84]. MaxEnt is useful for our analyses because it uses presence-only data combined with background data and because it performs well with the BIOCLIM variables. For each species, we generated 16 candidate models with the R package 'ENMeval 2.0' [85] using the following settings: partition method = 'block'; random points = 10,000; algorithm $=$ maxent.jar; regularization of multiplier values $=1-4$ with increments of 1 ; feature classes = L, Q, H, LQH [86]. For Isthmohyla angustilineata and I. pictipes, we used 'N-1 Jackknife' as partition method, aiming to maximize the limited available information on species occurrences $<25$ [87]. For each set of candidate models, we selected the model with the highest value of the average test of the area under the receiver characteristic operator curve (AUC mean) and the lowest omission rate at minimum training presence (orMTP) [88]. We used the selected settings (see Tables S1 and S2) to build climatic suitability maps with the R package 'dismo' [89]. We generated predictive binary maps (presence-absence) of the potentially suitable habitats of the treefrog species in Costa Rica using the equal training sensitivity and specificity threshold [90].

To quantify the historical suitable habitats of our focal species, we estimated two nonequivalent metrics. First, we calculated each species' extent of suitable habitat (ESH) [83] 
by transforming our predictive binary maps into a shapefile and estimating the available suitable area. Second, we calculated each species' area of minimum convex polygon $\left(\mathrm{A}_{\mathrm{MCP}}\right)$, which represents the area contained within the minimum convex polygon that can be drawn to encompass all the current known localities, as well as the inferred and projected occurrences of a species $[83,91]$.

\section{Results}

\subsection{Species Assessment}

Our updated list of Costa Rican treefrogs still includes 48 species classified in 14 genera and three families, as reported in the last assessment in 2019 [43]. Most treefrogs occur in the family Hylidae, with 41 species in 12 genera (Table 1). Isthmohyla and Smilisca are the richest genera, with 11 and 7 species, respectively. A total of four treefrog species is endemic to Costa Rica (Duellmanohyla rufioculis, Ecnomiohyla sukia, Isthmohyla pictipes, and I. xanthosticta), and one species is introduced (Osteopilus septentrionalis). According to the most recent IUCN Red List Assessment in 2019 [47], 18 treefrog species are classified in threatened categories, including one species that is possibly extinct (I. calypsa), and five are categorized as critically endangered (Table 1). Similarly, updated EVS show that $21 \%$ of the treefrog species are highly vulnerable to extinction (EVS of 14-17) (Table 1).

Table 1. List of the 48 known treefrog species in Costa Rica distributed by herpetological province and elevational range. For every taxon, numbers in square brackets indicate the number of genera, and numbers displayed in parenthesis indicate the number of species. The table also specifies the IUCN status reported after the global assessments in 2004 and 2019 and environmental vulnerability scores (EVS). Symbology for herpetological provinces: CL = Caribbean Lowlands; $\mathrm{CT}=$ the Talamanca mountain range; $\mathrm{MSCC}=$ Mountain Slopes and Central Mountain range; PN = Pacific Northwest; PS = Pacific Southwest. IUCN Red List categories: NA = Not Assessed; U = Unfinished; DD = Data Deficient; LC = Least Concern; NT = Near Threatened; VU = Vulnerable; EN = Endangered; $\mathrm{CR}=$ Critically Endangered; EX = Extinct in the wild; $\mathrm{PE}=$ Possibly Extinct. EVS categories: low vulnerability species (EVS of 3-9); medium vulnerability species (EVS of 10-13); high vulnerability species (EVS of 14-17).

\begin{tabular}{|c|c|c|c|c|c|c|c|c|c|}
\hline \multirow{2}{*}{ Amphibian Species } & \multirow{2}{*}{ EVS } & \multicolumn{2}{|c|}{ IUCN Status } & \multicolumn{5}{|c|}{ Distribution in Costa Rica } & \multirow{2}{*}{$\begin{array}{l}\text { Elevation } \\
\text { (m) }\end{array}$} \\
\hline & & 2004 & 2019 & CL & CT & MSCC & PN & PS & \\
\hline \multicolumn{10}{|c|}{ Hemiphractidae [1] (1) } \\
\hline Gastrotheca cornuta & 15 & EN & $\mathrm{U}$ & $X$ & & $X$ & & & $300-1000$ \\
\hline \multicolumn{10}{|c|}{ Hylidae [12] (40) } \\
\hline Boana rosenbergi & 10 & LC & LC & & & & $X$ & $X$ & 0-900 \\
\hline Boana rufitela & 10 & LC & LC & $X$ & & $X$ & & & $0-750$ \\
\hline Dendropsophus ebraccatus & 8 & LC & LC & $X$ & $X$ & $X$ & $X$ & $X$ & $0-1600$ \\
\hline Dendropsophus microcephalus & 7 & $\mathrm{LC}$ & $\mathrm{LC}$ & $X$ & $X$ & $X$ & $X$ & $X$ & $0-1200$ \\
\hline Dendropsophus phlebodes & 8 & $\mathrm{LC}$ & $\mathrm{LC}$ & $X$ & & $X$ & & & $0-750$ \\
\hline Duellmanohyla legleri & 13 & EN & $\mathrm{LC}$ & & & $X$ & & $X$ & $600-1500$ \\
\hline Duellmanohyla lythrodes & 14 & EN & $\mathrm{EN}$ & $X$ & & & & & $150-450$ \\
\hline Duellmanohyla rufioculis & 12 & $\mathrm{LC}$ & $\mathrm{LC}$ & $X$ & $X$ & $X$ & $X$ & $X$ & $650-1600$ \\
\hline Duellmanohyla uranochroa & 12 & $\mathrm{EN}$ & VU & $X$ & $X$ & $X$ & & & $300-1750$ \\
\hline Ecnomiohyla bailarina & 15 & NA & NT & $X$ & & & & & $300-750$ \\
\hline Ecnomiohyla fimbrimembra & 14 & EN & VU & & & $X$ & & & $750-1900$ \\
\hline Ecnomiohyla miliaria & 12 & VU & VU & $X$ & & $X$ & & $X$ & $0-1350$ \\
\hline Ecnomiohyla sukia & 14 & NA & LC & $X$ & & $X$ & & & $400-1000$ \\
\hline Ecnomiohyla veraguensis & 14 & NA & VU & $X$ & & & & & NE \\
\hline Hyloscirtus colymba & 9 & CR & EN & & & $X$ & & & $600-1200$ \\
\hline Hyloscirtus palmeri & 10 & LC & LC & $X$ & & $X$ & & & $400-1000$ \\
\hline Isthmohyla angustilineata & 10 & CR & CR & & $X$ & $X$ & $X$ & & $1500-2350$ \\
\hline Isthmohyla calypsa & 13 & CR & CR (PE) & & $X$ & & & & $1700-2300$ \\
\hline Isthmohyla debilis & 11 & CR & $\mathrm{CR}$ & & $X$ & $X$ & & & $900-1450$ \\
\hline Isthmohyla lancasteri & 10 & LC & LC & $X$ & & $X$ & & & $350-1400$ \\
\hline Isthmohyla picadoi & 14 & $\mathrm{LC}$ & $\mathrm{LC}$ & & $X$ & $X$ & & & $1700-2900$ \\
\hline Isthmohyla pictipes & 12 & EN & CR & & $X$ & $X$ & & & $1900-2800$ \\
\hline Isthmohyla pseudopuma & 8 & LC & LC & & $x$ & $x$ & & & $1100-2350$ \\
\hline Isthmohyla rivularis & 12 & CR & EN & & $X$ & $X$ & $X$ & & $1200-2450$ \\
\hline Isthmohyla tica & 10 & CR & CR & & $X$ & $X$ & $X$ & & $720-1750$ \\
\hline Isthmohyla xanthosticta & 14 & DD & DD & & & $x$ & & & 2150 \\
\hline Isthmohyla zeteki & 14 & NT & VU & & $X$ & $x$ & & & $1200-1800$ \\
\hline Osteopilus septentrionalis & 9 & LC & LC & $X$ & & & & & $0-10$ \\
\hline Scinax boulengeri & 6 & $\mathrm{LC}$ & $\mathrm{LC}$ & $X$ & & & $X$ & $X$ & $1-700$ \\
\hline Scinax elaeochroa & 8 & $\mathrm{LC}$ & $\mathrm{LC}$ & $X$ & $X$ & $x$ & $X$ & $X$ & $0-1200$ \\
\hline Scinax staufferi & 9 & LC & $\mathrm{LC}$ & $x$ & & & $x$ & & $0-700$ \\
\hline
\end{tabular}


Table 1. Cont

\begin{tabular}{|c|c|c|c|c|c|c|c|c|c|}
\hline \multirow{2}{*}{ Amphibian Species } & \multirow{2}{*}{ EVS } & \multicolumn{2}{|c|}{ IUCN Status } & \multicolumn{5}{|c|}{ Distribution in Costa Rica } & \multirow{2}{*}{$\begin{array}{l}\text { Elevation } \\
\text { (m) }\end{array}$} \\
\hline & & 2004 & 2019 & CL & CT & MSCC & PN & PS & \\
\hline Smilisca baudinii & 6 & LC & LC & & & $X$ & $X$ & $X$ & $0-1600$ \\
\hline Smilisca manisorum & 8 & NA & $\mathrm{LC}$ & $X$ & & & & & $0-750$ \\
\hline Smilisca phaeota & 6 & $\mathrm{LC}$ & $\mathrm{LC}$ & $X$ & & $X$ & $X$ & $X$ & $0-1100$ \\
\hline Smilisca puma & 9 & $\mathrm{LC}$ & $\mathrm{LC}$ & $X$ & & & & & $0-550$ \\
\hline Smilisca sila & 10 & $\mathrm{LC}$ & $\mathrm{LC}$ & & $X$ & $X$ & $X$ & $X$ & $0-1000$ \\
\hline Smilisca sordida & 7 & $\mathrm{LC}$ & $\mathrm{LC}$ & $X$ & $X$ & $X$ & $x$ & $x$ & $0-1550$ \\
\hline Tlalocohyla loquax & 9 & $\mathrm{LC}$ & $\mathrm{LC}$ & $X$ & & $X$ & & & $50-1100$ \\
\hline Trachycephalus typhonius & 7 & $\mathrm{LC}$ & $\mathrm{LC}$ & $X$ & & $X$ & $X$ & $X$ & $0-1100$ \\
\hline Triprion spinosus & 12 & $\mathrm{LC}$ & NT & $X$ & & $X$ & & $X$ & $100-1400$ \\
\hline \multicolumn{10}{|c|}{ Phyllomedusidae [2] (7) } \\
\hline Agalychnis annae & 10 & LC & VU & & $X$ & $X$ & $X$ & & $780-1650$ \\
\hline Agalychnis callidryas & 8 & LC & LC & $X$ & & $x$ & $X$ & $X$ & $0-1250$ \\
\hline Agalychnis lemur & 11 & CR & CR & $X$ & & $X$ & & & $450-1600$ \\
\hline Agalychnis saltator & 8 & LC & $\mathrm{LC}$ & $X$ & & $x$ & & & $0-1000$ \\
\hline Agalychnis spurrelli & 11 & $\mathrm{LC}$ & $\mathrm{LC}$ & $X$ & & $X$ & & $X$ & 0-900 \\
\hline Cruziohyla calcarifer & 14 & $\mathrm{LC}$ & $\mathrm{LC}$ & $X$ & & & & & $0-800$ \\
\hline Cruziohyla sylviae & 12 & NA & LC & $X$ & & & & & $0-800$ \\
\hline
\end{tabular}

\subsection{Suitable Habitat}

Agalychnis annae: Our results show that high environmental suitability for this species occurs across mountain ranges, especially along the Central Mountain range and certain mountain areas of southern Costa Rica in Coto Brus county. This species appears to have recovered in most of its historical range and has been observed in regions where it was unknown before, especially urban areas (Figure 3a). Our climatic suitability map also predicts the occurrence of this species in western Panama.

Agalychnis lemur: Environmental suitability is high for this species across mountain ranges, especially on the Caribbean slope. Currently, this species only occurs across the Caribbean slopes of the Talamanca mountain range, especially at elevations from 400 to $600 \mathrm{~m}$. It has been frequently observed in most of these regions, which suggests some populations are large and stable. The species appears to have been completely extirpated from the Central and Tilarán mountain ranges (Figure 3b).

Duellmanohyla uranochroa: We found high suitability across mountain ranges, especially on the Caribbean slope. This species appears to have been extirpated from most of its historical range, especially on the Central and Guanacaste mountain ranges. Several populations have been observed in mid-elevations across the Caribbean slope of the Talamanca mountain range, including observations along contaminated, fast-flowing streams. This species also appears to exhibit a slow recovery in the Tilarán mountain range, and it probably occurs on the Pacific side of the Talamanca mountain range (Figure 3c).

Ecnomiohyla sukia: We found that suitability for this species is high on the Caribbean slope of the Central and Talamanca mountain ranges. Currently, the species appears to be widespread on the Caribbean side of Costa Rica and northern lowlands, including tropical and premontane primary and secondary forests (Figure 4a). Our predictions suggest that this species might occur in Panama, on both the Caribbean and Pacific slopes of the Panamanian side of the Talamanca mountain range.

Isthmohyla angustilineata: We found high suitability for this species across mountain ranges, especially on the Caribbean slope. The species appears to have been extirpated from most of the east side of the Talamanca mountain range but persists in small parts of its historical range, especially in undisturbed highland pools and swamps across the Central and Tilarán mountain ranges (Figure 3d).

Isthmohyla pictipes: We found high suitability for this species across the Central and Talamanca mountain ranges, especially on the Caribbean slope. The species appears to have been extirpated across the Central mountain range. However, it has been reobserved in small numbers in certain areas of its historical range, specifically in fast-flowing streams in the Pacific versant of the Talamanca mountain range (Figure 3e). 


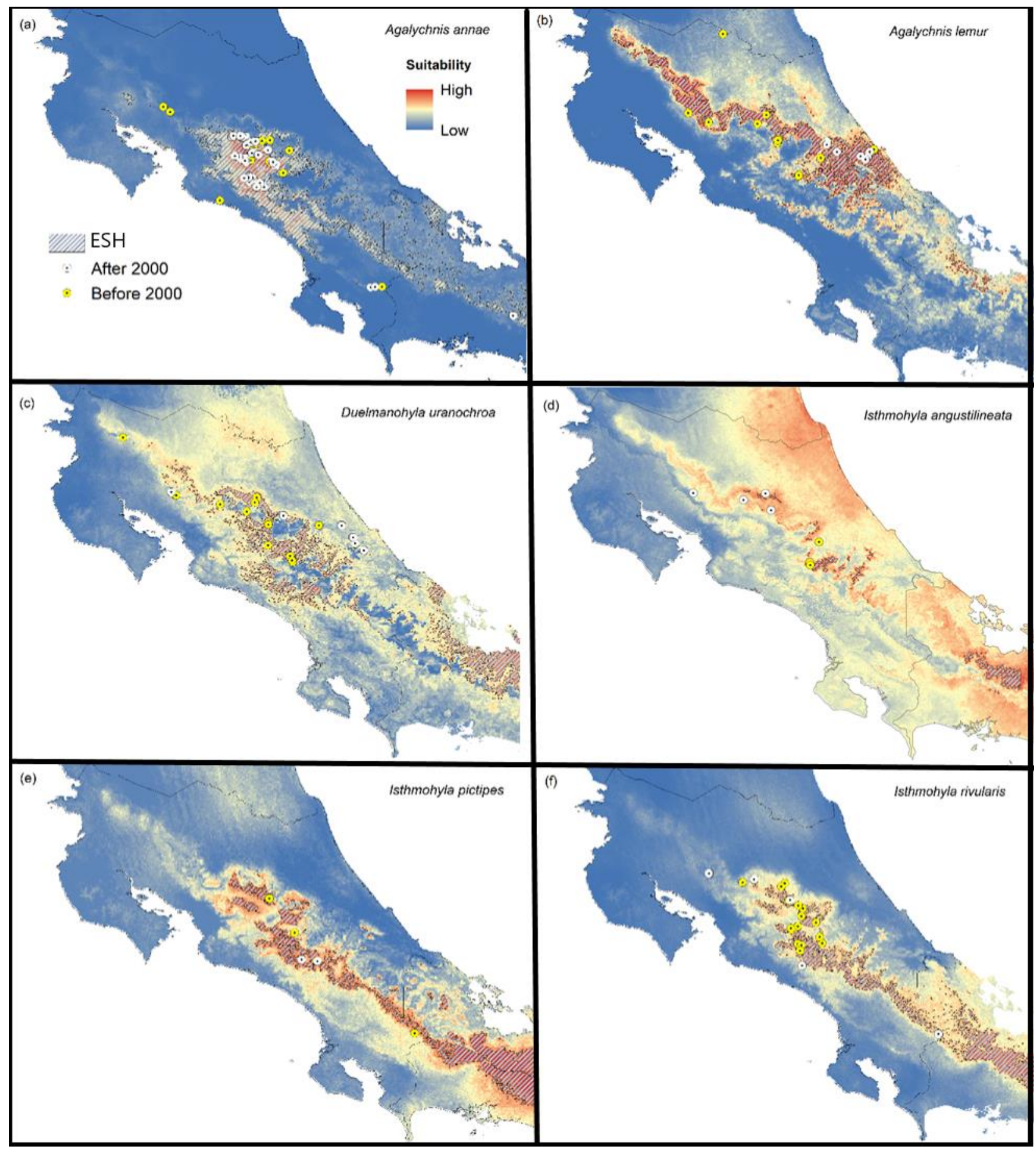

Figure 3. Species recovery. Climatic suitability maps for six treefrog species that are exhibiting recovery in Costa Rica. The figure also shows a polygon representing the historic extent of suitable habitat (ESH), occurrences reported after 2000 (white dots), and locations where the species was found before 2000 but not after (yellow dots); (a) blue-sided treefrog (Agalychnis annae); (b) lemur leaf frog (Agalychnis lemur); (c) Costa Rica brook frog (Duellmanohyla uranochroa); (d) narrowlined treefrog (Isthmohyla angustilineata); (e) Pico Blanco treefrog (Isthmohyla pictipes); (f) American cinchona plantation treefrog (Isthmohyla rivularis). 


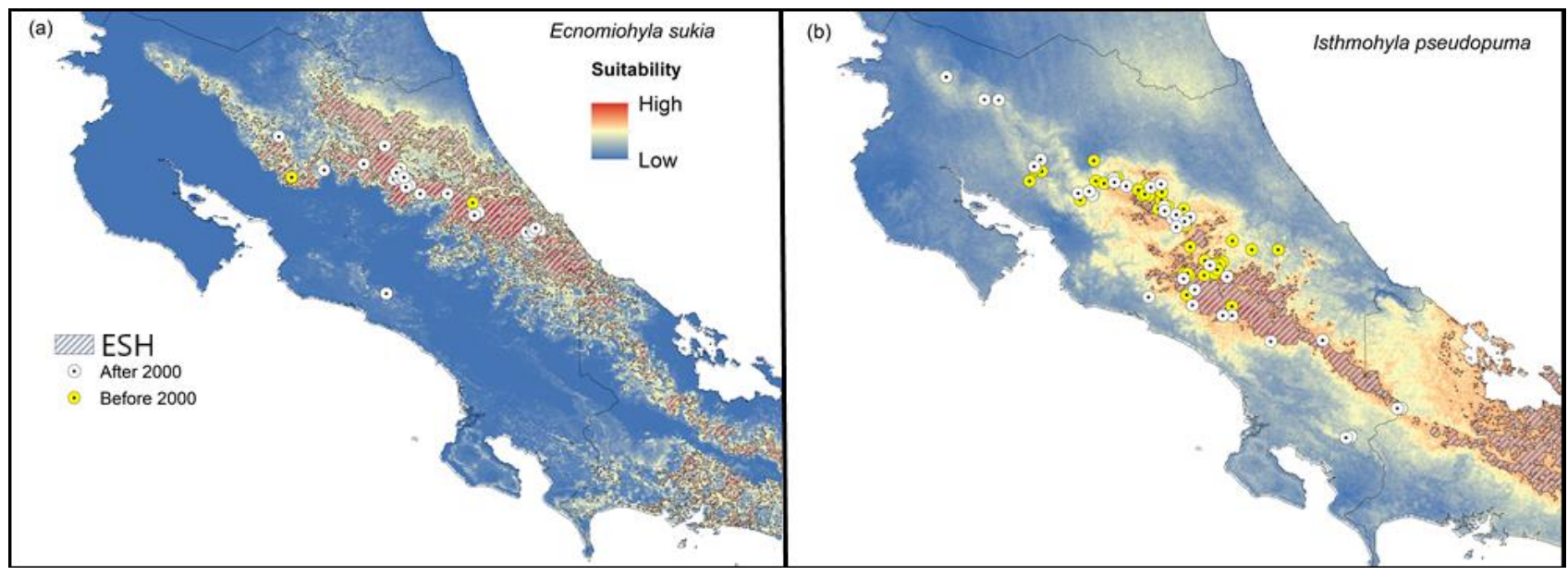

Figure 4. Widespread uncommon species and rapid-spread species. Climatic suitability maps for the uncommon and widespread (a) Shaman fringe-limbed treefrog (Ecnomiohyla sukia) and (b) the potential Bd-reservoir Gunther's Costa Rican treefrog (Isthmohyla pseudopuma). The figure also shows a polygon representing the historic extent of suitable habitat (ESH), occurrences reported after 2000 (white dots), and locations where the species was found before 2000 but not after (yellow dots).

Isthmohyla pseudopuma: Our results show high suitability across mountain ranges, especially on the Pacific slope. This species has expanded its range across the Talamanca and Guanacaste mountain ranges (Figure $4 b$ ).

Isthmohyla rivularis: Environmental suitability for this species is high across the Central and Talamanca mountain ranges. This species has been reobserved in a large fraction of its historical range and appears to be slowly recovering across the Tilarán, Central, and Talamanca mountain ranges. However, sightings are still sporadic compared to pre-decline times (Figure 3f).

\subsection{Suitable Habitat}

We found that the ESH of species that have recovered only in small areas of their historic ranges is approximately $32-49 \%$ smaller than the $\mathrm{A}_{\mathrm{MCP}}$. However, this difference showed an opposite trend for species that have recovered in most of their range or rare species with a wide range (Table 2), which suggests that IUCN range polygons for these species should be updated. For I. rivularis, the ESH was only $5 \%$ smaller than the $\mathrm{A}_{\mathrm{MCP}}$. For $A$. annae, which exhibits the widest recovery, the ESH was $129 \%$ greater than the $A_{M C P}$. Similarly, the ESH of the widespread I. sukia was $124 \%$ greater than the $\mathrm{A}_{\mathrm{MCP}}$.

Table 2. Estimations of the extent of suitable habitat (ESH) and the area of minimum convex polygon $\left(\mathrm{A}_{\mathrm{MCP}}\right)$. The table also shows the percent of the difference in area by comparing the ESH against the $\mathrm{A}_{\mathrm{MCP}}$.

\begin{tabular}{cccc}
\hline Species & ESH $\mathbf{( k m}^{\mathbf{2}} \mathbf{)}$ & $\mathbf{A}_{\mathbf{M C P}} \mathbf{( k m}^{\mathbf{2}} \mathbf{)}$ & Difference (\%) \\
\hline Agalychnis annae & 6373.9 & 2778.3 & +129.4 \\
Agalychnis lemur & 4352.7 & 7489.4 & -41.9 \\
Duellmanohyla uranochroa & 2853.6 & 5574.3 & -48.9 \\
Ecnomiohyla sukia & 6515.2 & 2905.8 & +124.2 \\
Isthmohyla angustilineata & 238.0 & 400.0 & -40.5 \\
Isthmohyla pictipes & 1891.6 & 2797.0 & -32.4 \\
Isthmohyla pseudopuma & 3212.5 & 4781.9 & -32.8 \\
Isthmohyla rivularis & 2237.6 & 2359.0 & -5.1 \\
\hline
\end{tabular}




\section{Discussion}

\subsection{Species Assessment}

The number of known treefrog species (48 species in three families) has not changed since the most recent list of Costa Rican amphibians in 2019 [43]. However, the continuous monitoring of declined amphibians in Costa Rica and the most recent IUCN Red List Assessment [47] gave rise to changes in the status of amphibian species, including treefrogs (Table 1). Five species of treefrogs (Duellmanohyla legleri, D. uranochroa, Ecnomiohyla fimbrimembra, Hyloscirtus colymba, and Isthmohyla rivularis) now exhibit a less threatened status. Four species were moved into more threatened categories (Agalychnis annae, Isthmohyla calypsa, I. zeteki, and Triprion spinosus). Five species were assessed for the first time (Ecnomiohyla bailarina, E. sukia, E. veraguensis, Smilisca manisorum, and Cruziohyla sylviae), and the species Gastrotheca cornuta is still being evaluated by the IUCN Species Survival Commission, Amphibian Specialist Group. According to EVS, a total of ten species of treefrogs $(21 \%)$ is classified as highly vulnerable to extinction (Table 1$)$. Of these, only I. calypsa is classified as critically endangered (possibly extinct) by the IUCN.

\subsection{Spread Patterns}

\subsubsection{Species Recovery}

We found that six of our study species (Agalychnis annae, A. lemur, Duellmanohyla uranochroa, Isthmohyla angustilineata, I. pictipes, and I. rivularis) have exhibited recovery since the early 2000s, but apparently at different rates (i.e., time for a species to recover across the historical range after the declines of the 1980s and 1990s). The fastest recovery has been observed in A. annae (Figure 3a). It declined to its full extent during the 1980s and 1990s, and only one remnant population was known for a while $[52,54,56]$. However, it recovered in most of its range and has become a common species in urban and disturbed areas $[9,70]$. Due to this fast recovery after 2010, A. annae was originally classified as least concern in a previous IUCN Red List workshop [49]; however, it was reclassified to vulnerable in the most recent workshop [47] based on new criteria. Here, this species has been observed successfully breeding/foraging in artificial water containers such as fountains, ditches, sinks, and old tires (Figure 5a). It is very susceptible to mortality from vehicles, especially in urban areas (Figure $5 b$ ). In addition to urban populations, A. annae has been recently reported in riparian forests, springs, and pristine areas in the Central and South Pacific mountains [70], which suggest the recovery has also occurred in undisturbed ecosystems (V. Acosta-Chaves, unpublished). Our suitability map, as well as recent reports from Panama [55], suggest that $A$. annae historically occurs in this country but had not been detected previously.

We also found that Agalychnis lemur and Isthmohyla rivularis appear to be experiencing a stable recovery across part of their historical ranges (Figure $3 \mathrm{~b}$ and f) $[58,59,71]$. However, A. lemur appears to have gone locally extinct in a large part of its range outside Talamanca, and $I$. rivularis remains undetectable in most of the Central mountain range. In this regard, the current occurrence of several populations of A. lemur across the central Caribbean was probably favored by reintroductions in the region around the 2000s. Conversely, Duellmanohyla uranochroa, I. angustilineata, and I. pictipes (Figure 3c-e) appear to be experiencing a slower recovery $[47,61,64,92]$, and they have probably been extirpated from most of their historical ranges. Although most of the known remnant populations of these species (and other endangered species) are under both private and state protection [64], they are still threatened by illegal activities that occur within these areas, such as logging, squatters, illegal tourism, poaching, and a deficit of resources to provide continuous surveillance (V. Acosta-Chaves, unpublished). Similar scenarios are probably faced by other declined treefrog species with similar ecologies, such as Starret's treefrog (Isthmohyla tica; Figure 6a) (J. Santamaría, personal observation). 


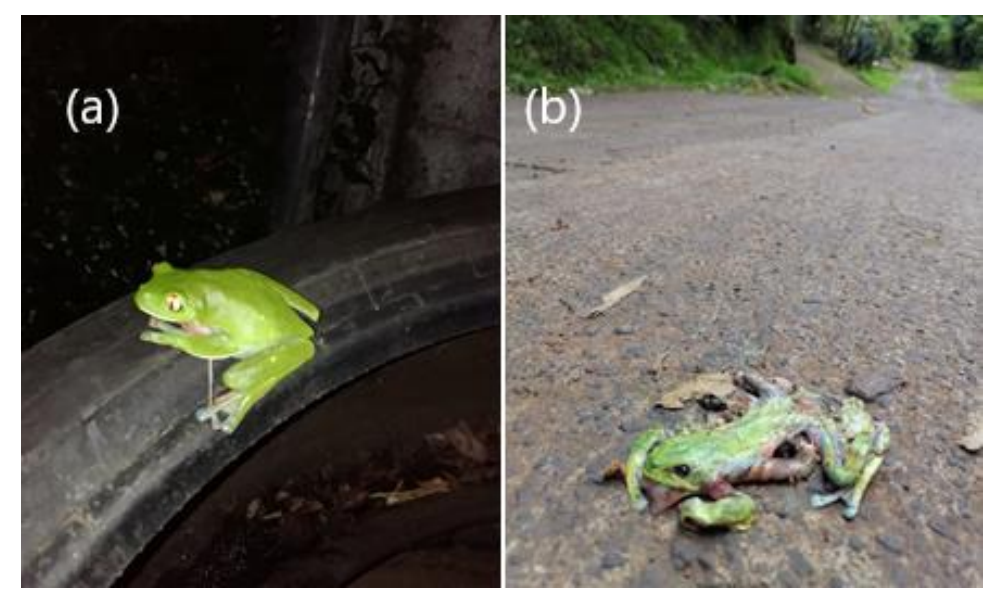

Figure 5. Blue-sided treefrog (Agalychnis annae); (a) use of artificial containers in urban environments as breeding/foraging sites (picture, Kathia Alfaro); (b) roadkill in an urban area of the province of San Jose, Costa Rica (picture, Gustavo Murillo and Naomi Méndez). Reproduced with permission from Kathia Alfaro, Gustavo Murillo and Naomi Méndez.
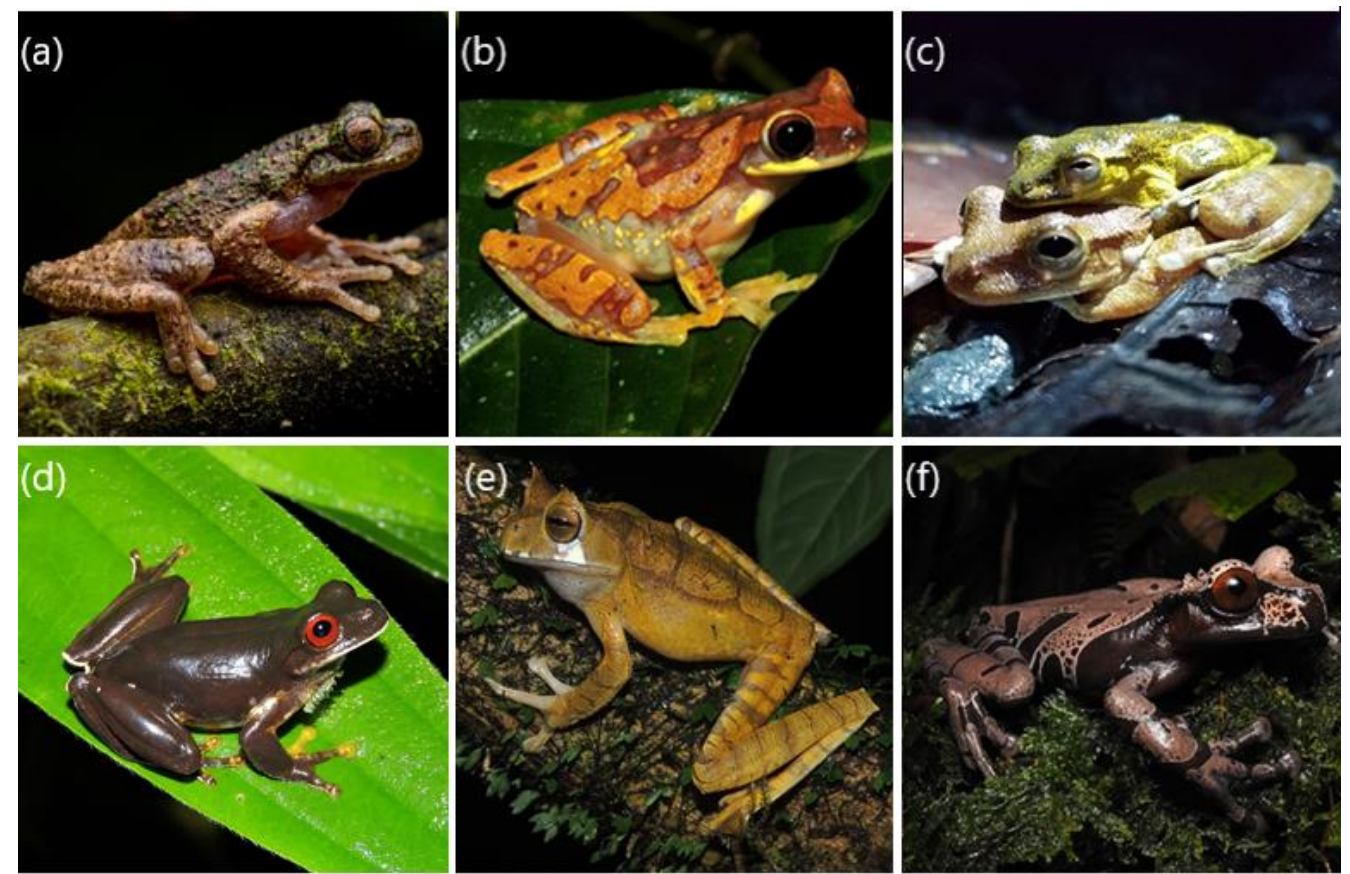

Figure 6. Spread patterns. Species recovery: (a) the Starret's treefrog, Isthmohyla tica; (picture, Jerson Santamaría and Pablo Marín) seems to be slowly recovering in part of its range. Rapid spread: (b) the harlequin treefrog, Dendropsophus ebraccatus (picture, Víctor Acosta-Chaves) and (c) the drab treefrog, Smilisca sordida (picture, Héctor Zumbado-Ulate) seem to have increased their ranges since the 2000s or earlier, perhaps taking advantage of the decline of other sympatric species. Widespread uncommon species: (d) the Legler's treefrog, Duellmanohyla legleri, (picture, Victor Acosta-Chaves), (e) the horned treefrog, Gastrotheca cornuta (picture, Stanley Salazar), and (f) the spiny-headed treefrog, Triprion spinosus (picture, Stanley Salazar) are uncommon species that have been more frequently sighted in the last decade. Reproduced with permission from Jerson Santamaría and Pablo Marín.

Several mechanisms, acting alone or synergistically, may explain the persistence and resilience of these species, especially those susceptible to $B d$. For example, some remnant populations may have (1) persisted in areas where environmental factors reduce pathogen transmission [93-95], (2) rapidly evolved reduced susceptibility to $B d$ [96], or (3) recovered after a decrease in the prevalence of disease due to low host abundance [97]. Furthermore, 
some of these species could have increased their detectability as a result of (1) relocations and introductions, (2) construction of artificial breeding sites, or (3) management in public and private protected areas.

\subsubsection{Rapid Spread}

We found evidence that Isthmohyla pseudopuma increased its range since the 2000s or earlier, perhaps taking advantage of the decline of other sympatric, pond-breeding species caused by epizootic outbreaks of $B d$ (i.e., pathogen-mediated competition) [98]. Therefore, I. pseudopuma might be a $B d$-reservoir species [99] that is affecting the recovery of species such as I. angustilineata and the Holdridge's toad, Incilius holdridgei. Similarly, other treefrog species, such as the iconic red-eyed treefrog, Agalychnis callidryas, the harlequin treefrog, Dendropsophus ebraccatus (Figure 6b), the drab treefrog, Smilisca sordida (Figure 6c), and the masked treefrog, S. phaeota, appear to have increased their ranges after the historic amphibian declines and might also be tolerant of $B d$ infection and therefore $B d$-reservoir species $[100,101]$.

\subsubsection{Widespread Uncommon Species}

Long-term amphibian monitoring in Costa Rica and the results of the most recent IUCN Red List workshops [47] have allowed researchers to better understand the ranges and natural history of uncommon and data-deficient species and, therefore, increase the number of sightings of some species. In this paper, we have shown that the uncommon Ecnomiohyla sukia is widespread and probably occurs on both the Caribbean and Pacific slopes of Costa Rica and Panama. For example, the record of a new locality for E. miliaria on the Pacific coast of Costa Rica [73] probably represents a record of E. sukia (S. Salazar and V. Acosta-Chaves, unpublished). Our results provide a framework for a more detailed study of the range, ecology, and reproductive behavior (e.g., call description, breeding sites) of uncommon species that have been more frequently sighted in the last decade, such as Palmer's treefrog (Hyloscirtus palmeri), Legler's stream frog (Duellmanohyla legleri; Figure 6d), the Volcan Barva treefrog (Isthmohyla picadoi), Zetek's treefrog (I. zeteki), the horned marsupial frog (Gastrotheca cornuta; Figure 6e), and the spiny-headed treefrog (Triprion spinosus; Figure $6 f)[7,51,58,69,102]$. A better understanding of the use and occupancy of the habitat is fundamental to providing a more accurate status of these elusive species.

\subsection{Study Limitations}

One of the greatest limitations of this type of study is gathering accurate data from many different sources. Although we support the protection of the specific locations of remnant populations, the reporting of 'obscured coordinates' (i.e., alteration of true geographic coordinates to hide the real location of occurrence points (see https: / / www. inaturalist.org/pages/help\#geoprivacy accessed on 1 September 2021) can introduce a significant geographic bias. Therefore, we excluded numerous 'obscured' coordinates from our analyses. We recommend that conservation agencies and federal agencies (e.g., the Sistema Nacional de Áreas Protegidas, SINAC, and the Comisión Nacional para la Gestión de la Diversidad, CONAGEBIO) develop data-delivery protocols through a confidential, efficient, and ethical system to disclose the accurate coordinates to researchers that are conducting conservation studies that rely on geographic analyses.

\subsection{Implications for Conservation}

Our methods can be used to predict the suitable habitat of amphibian species and other taxa and will be useful in future IUCN Red List Assessments of Costa Rican species. Similarly, our predictions can be used in follow-up studies to conduct validation surveys in areas of high suitability where there have been rare or absent efforts to detect study species.

We used two metrics to assess our estimated ranges. The ESH is a more robust metric because it quantifies suitable habitats [83]. However, this metric can be estimated only for species with comprehensive, updated, and curated occurrence datasets. Unfortunately, this 
information is not available for many species, making other metrics (e.g., $\mathrm{A}_{\mathrm{MCP}}$ ) useful tools to assess the species' status. Instead of adhering to a particular metric, we recommend estimating at least two metrics (as we did in this study) to assess the ranges of species. For example, we found that species that have only recovered in a small portion of their historical ranges had an ESH significantly lower (32-49\%) than the $\mathrm{A}_{\mathrm{MCP}}$. However, species that have widely recovered, as well as uncommon widespread species, had a similar or larger ESH than $\mathrm{A}_{\mathrm{MCP}}$ (Table 2). Using at least two metrics can facilitate the analyses of conservative and less conservative scenarios in the development of management strategies. It also allows the identification of IUCN range polygons that need to be rebuilt to better reflect species' ranges. Finally, our results can also be used by policymakers (e.g., Costa Rican Congress, local government boards), federal agencies (e.g., SINAC and CONAGEBIO), and NGOs to evaluate the national regulations for biodiversity conservation and amend or propose new laws to protect endangered species.

According to Costa Rican legislation, amphibians are mainly protected by the Wildlife Conservation Law No. 7317 and Biodiversity Law No. 7788, as well as related decrees. As a result of conservation efforts and IUCN Red List Assessments, the treefrog species Agalychnis lemur, Duellmanohyla legleri, Hyloscirtus colymba (La Loma treefrog), Isthmohyla angustilineata, I. pictipes, I. tica, I. rivularis, I. calypsa, and I. debilis (Isla Bonita treefrog) are now included in the official list of species at risk of extinction (decree R- SINAC-CONAC092-2017), and we hope new species will be included. Additionally, the leaf frogs within the genus Agalychnis are in the II Appendix of CITES (https: / / cites.org/eng accessed on 1 September 2021). Thus, there is still a deficit of protection for many endangered amphibian species in Costa Rica, including some assessed in our study. On the other hand, multiple conservation organizations, federal agencies, and commercial services in Costa Rica have frequently used the red-eyed treefrog, $A$. callidryas, as a flag species in all types of advertisement, especially for ecotourism. As a valuable strategy to bring awareness from Costa Rican people to the conservation of amphibians, we recommend the Government of Costa Rica entitle an endangered amphibian species as a national symbol. This strategy has been successfully applied to protect other species from different taxa, such as the three-toed sloth (Bradypus variegatus) and the manatee (Trichechus manatus). Some treefrogs could be candidates, for example, $A$. annae and $A$. callidryas. Other treefrog species can be used as regional wildlife flag species, such as $A$. lemur, Cruziohyla calcarifer (splendid treefrog), C. sylviae (Sylvia's treefrog), D. uranochroa, Ecnomiohyla sukia, H. palmeri, I. pictipes, I. rivularis, and Triprion spinosus. Outreach and conservation projects in communities where declined amphibians have been reobserved can be fundamental to the destruction of popular, negative myths about amphibians and educate the public on the ecosystem services provided by amphibians [103].

Supplementary Materials: The following are available online https:/ / www.mdpi.com/article/10.339 0/d13110577/s1: Table S1. Best-fitted candidate models selected to predict the range of eight species of treefrogs in Costa Rica, Table S2. Permutation importance (\%) of the environmental predictors used to model the range of eight species of treefrogs in Costa Rica.

Author Contributions: Conceptualization, H.Z.-U.; Data curation, H.Z.-U., G.C., V.A.-C. and A.G.-R.; Formal analysis, H.Z.-U., G.C. and A.G.-R.; Methodology, H.Z.-U., C.L.S., G.C., V.A.-C., A.S., S.S. and A.G.-R.; Project administration, H.Z.-U., C.L.S., G.C. and A.G.-R.; Supervision, H.Z.-U. and C.L.S.; Writing - original draft, H.Z.-U., G.C., V.A.-C. and A.S.; Writing-review and editing, H.Z.-U., C.L.S., G.C., V.A.-C., A.S., S.S. and A.G.-R. All authors have read and agreed to the published version of the manuscript.

Funding: HZ-U was funded by (1) the Purdue University Research Foundation, (2) the Osa Conservation through the Álvaro Ugalde Scholarship, and (3) IdeaWild.

Institutional Review Board Statement: This study was conducted with the approval of the Costa Rican Ministry of Environment and Energy (MINAE; Research permits 001-2012-SINAC, SINAC-SEGASP-PI-R-072-2104, R-019-2016-OT-CONAGEBIO, R-023-2016-OT-CONAGEBIO, R-057-2016-OTCONAGEBIO, R-060-2016-OT-CONAGEBIO, R-022-2017-OT-CONAGEBIO). 
Informed Consent Statement: Not applicable.

Data Availability Statement: Data will be permanently archived in the Purdue University Research Repository (PURR; https:/ / purr.purdue.edu/ accessed on 1 September 2021).

Acknowledgments: We thank Federico Bolaños, Gilbert Alvarado, Fabiola Ureña, Kathia Alfaro, Jhon Cossel Jr., Alejandra Camacho, Byron Araya, Andrey Solís, Fabio Hidalgo, Paula Acosta, María José Cascante, Henry Sandí, Henry Fallas, Alejandra Rodríguez, Adrián Delgado, Ana Murillo, Francisco Vargas, Jerson Santamaría, Pablo Marín, Gustavo Murillo, Naomi Méndez, Alejandro Sandí. We also thank Michelle Monge (INaturalist Costa Rica), and José Alfredo Hernández (CONAGEBIO) for providing access to data, pictures, and occurrence points.

Conflicts of Interest: The authors declare no conflict of interest. The funders had no role in the design of the study; in the collection, analyses, or interpretation of data; in the writing of the manuscript; and in the decision to publish the results.

\section{References}

1. Frost, D.R. Amphibian Species of the World: An Online Reference. Version 6.1. 2021. Available online: https:// amphibiansoftheworld.amnh.org/ (accessed on 1 September 2021).

2. Pyron, R.A.; Wiens, J.J. Large-Scale Phylogenetic Analyses Reveal the Causes of High Tropical Amphibian Diversity. Proc. R. Soc. B Biol. Sci. 2013, 280, 20131622. [CrossRef]

3. Sewell, D.; Griffiths, R.A. Can a Single Amphibian Species Be a Good Biodiversity Indicator? Diversity 2009, 1, 102. [CrossRef]

4. Hocking, D.J.; Babbitt, K.J. Amphibian Contributions to Ecosystem Services. Herpetol. Conserv. Biol. 2014, 9, 1-17.

5. Whiles, M.R.; Lips, K.R.; Pringle, C.M.; Kilham, S.S.; Bixby, R.J.; Brenes, R.; Connelly, S.; Colon-Gaud, J.C.; Hunte-Brown, M.; Huryn, A.D.; et al. The Effects of Amphibian Population Declines on the Structure and Function of Neotropical Stream Ecosystems. Front. Ecol. Environ. 2006, 4, 27-34. [CrossRef]

6. Wiens, J.J. Global Patterns of Diversification and Species Richness in Amphibians. Am. Nat. 2007, 170, S86-S106. [CrossRef] [PubMed]

7. Duellman, W.E. The Hylid Frogs of Middle America; Natural History Museum, University of Kansas: Lawrence, KS, USA, 1970.

8. Wiens, J.J.; Graham, C.H.; Moen, D.S.; Smith, S.A.; Reeder, T.W. Evolutionary and Ecological Causes of the Latitudinal Diversity Gradient in Hylid Frogs: Treefrog Trees Unearth the Roots of High Tropical Diversity. Am. Nat. 2006, 168, 579-596. [CrossRef]

9. Savage, J.M. The Amphibians and Reptiles of Costa Rica: A Herpetofauna between Two Continents, between Two Seas; The University of Chicago Press: Chicago, IL, USA, 2002.

10. Becker, C.G.; Fonseca, C.R.; Haddad, C.F.B.; Prado, P.I. Habitat Split as a Cause of Local Population Declines of Amphibians with Aquatic Larvae. Conserv. Biol. 2010, 24, 287-294. [CrossRef] [PubMed]

11. Catenazzi, A. State of the World's Amphibians. Annu. Rev. Environ. Resour. 2015, 40, 91-119. [CrossRef]

12. Longcore, J.E.; Pessier, A.P.; Nichols, D.K. Batrachochytrium dendrobatidis Gen. et Sp. Nov., a Chytrid Pathogenic to Amphibians. Mycologia 1999, 91, 219-227. [CrossRef]

13. Berger, L.; Speare, R.; Daszak, P.; Green, D.E.; Cunningham, A.A.; Goggin, C.L.; Slocombe, R.; Ragan, M.A.; Hyatt, A.D.; McDonald, K.R.; et al. Chytridiomycosis Causes Amphibian Mortality Associated with Population Declines in the Rain Forests of Australia and Central America. Proc. Natl. Acad. Sci. USA 1998, 95, 9031-9036. [CrossRef] [PubMed]

14. Voyles, J.; Young, S.; Berger, L.; Campbell, C.; Voyles, W.F.; Dinudom, A.; Cook, D.; Webb, R.; Alford, R.A.; Skerratt, L.F.; et al. Pathogenesis of Chytridiomycosis, a Cause of Catastrophic Amphibian Declines. Science 2009, 326, 582-585. [CrossRef]

15. Lips, K.R.; Reeve, J.D.; Witters, L.R. Ecological Traits Predicting Amphibian Population Declines in Central America. Conserv. Biol. 2003, 17, 1078-1088. [CrossRef]

16. Ranvestel, A.W.; Lips, K.R.; Pringle, C.M.; Whiles, M.R.; Bixby, R.J. Neotropical Tadpoles Influence Stream Benthos: Evidence for the Ecological Consequences of Decline in Amphibian Populations. Freshw. Biol. 2004, 49, 274-285. [CrossRef]

17. Scheele, B.C.; Pasmans, F.; Skerratt, L.F.; Berger, L.; Martel, A.; Beukema, W.; Acevedo, A.A.; Burrowes, P.A.; Carvalho, T.; Catenazzi, A.; et al. Amphibian Fungal Panzootic Causes Catastrophic and Ongoing Loss of Biodiversity. Science 2019, 363, 1459-1463. [CrossRef]

18. Lambert, M.R.; Womack, M.C.; Byrne, A.Q.; Hernández-Gómez, O.; Noss, C.F.; Rothstein, A.P.; Blackburn, D.C.; Collins, J.P.; Crump, M.L.; Koo, M.S.; et al. Comment on "Amphibian Fungal Panzootic Causes Catastrophic and Ongoing Loss of Biodiversity". Science 2020, 367, eaay1838. [CrossRef] [PubMed]

19. Lips, K.R.; Diffendorfer, J.; Mendelson, J.R.; Sears, M.W. Riding the Wave: Reconciling the Roles of Disease and Climate Change in Amphibian Declines. PLoS Biol. 2008, 6, e72. [CrossRef] [PubMed]

20. Cheng, T.L.; Rovito, S.M.; Wake, D.B.; Vredenburg, V.T. Coincident Mass Extirpation of Neotropical Amphibians with the Emergence of the Infectious Fungal Pathogen Batrachochytrium dendrobatidis. Proc. Natl. Acad. Sci. USA 2011, 108, $9502-9507$. [CrossRef] [PubMed]

21. Pounds, J.A.; Crump, M.L. Amphibian Declines and Climate Disturbance: The Case of the Golden Toad and the Harlequin Frog. Conserv. Biol. 1994, 8, 72-85. [CrossRef] 
22. Crump, M.L.; Hensley, F.R.; Clark, K.L. Apparent Decline of the Golden Toad: Underground or Extinct? Copeia 1992, $1992,413-420$. [CrossRef]

23. Lips, K.R. Decline of a Tropical Montane Amphibian Fauna. Conserv. Biol. 1998, 12, 106-117. [CrossRef]

24. Puschendorf, R.; Bolaños, F.; Chaves, G. The Amphibian Chytrid Fungus along an Altitudinal Transect before the First Reported Declines in Costa Rica. Biol. Conserv. 2006, 132, 136-142. [CrossRef]

25. Puschendorf, R.; Carnaval, A.C.; VanDerWal, J.; Zumbado-Ulate, H.; Chaves, G.; Bolaños, F.; Alford, R.A. Distribution Models for the Amphibian Chytrid Batrachochytrium dendrobatidis in Costa Rica: Proposing Climatic Refuges as a Conservation Tool. Divers. Distrib. 2009, 15, 401-408. [CrossRef]

26. Bolaños, F. Situación de Los Anfibios de Costa Rica. Biocenosis 2009, 22, 95-108.

27. Zumbado-Ulate, H.; García-Rodríguez, A.; Searle, C.L. Species Distribution Models Predict the Geographic Expansion of an Enzootic Amphibian Pathogen. Biotropica 2021, 53, 221-321. [CrossRef]

28. Bolom-Huet, R.; Pineda, E.; Díaz-Fleischer, F.; Muñoz-Alonso, A.L.; Galindo-González, J. Known and Estimated Distribution in Mexico of Batrachochytrium dendrobatidis, a Pathogenic Fungus of Amphibians. Biotropica 2019, 51, 731-746. [CrossRef]

29. Brem, F.; Lips, K. Batrachochytrium dendrobatidis Infection Patterns among Panamanian Amphibian Species, Habitats and Elevations during Epizootic and Enzootic Stages. Dis. Aquat. Organ. 2008, 81, 189-202. [CrossRef] [PubMed]

30. Zumbado-Ulate, H.; García-Rodríguez, A.; Vredenburg, V.T.; Searle, C.L. Infection with Batrachochytrium dendrobatidis Is Common in Tropical Lowland Habitats: Implications for Amphibian Conservation. Ecol. Evol. 2019, 9, 4917-4930. [CrossRef]

31. Woodhams, D.C.; Kilburn, V.L.; Reinert, L.K.; Voyles, J.; Medina, D.; Ibáñez, R.; Hyatt, A.D.; Boyle, D.G.; Pask, J.D.; Green, D.M.; et al. Chytridiomycosis and Amphibian Population Declines Continue to Spread Eastward in Panama. EcoHealth 2008, 5, 268-274. [CrossRef]

32. Knapp, R.A.; Fellers, G.M.; Kleeman, P.M.; Miller, D.A.W.; Vredenburg, V.T.; Rosenblum, E.B.; Briggs, C.J. Large-Scale Recovery of an Endangered Amphibian despite Ongoing Exposure to Multiple Stressors. Proc. Natl. Acad. Sci. USA 2016, 113, 11889. [CrossRef]

33. Reeder, N.M.M.; Pessier, A.P.; Vredenburg, V.T. A Reservoir Species for the Emerging Amphibian Pathogen Batrachochytrium dendrobatidis Thrives in a Landscape Decimated by Disease. PLoS ONE 2012, 7, e33567. [CrossRef]

34. Taylor, E.H. A Review of the Frogs and Toads of Costa Rica. Univ. Kans. Sci. Bull. 1952, 35, 577-941. [CrossRef]

35. Robinson, D.C. A New Dwarf Salamander of the Genus Bolitoglossa (Plethodontidae) from Costa Rica. Proc. Biol. Soc. Wash. 1976, 89, 289-294.

36. García-París, M.; Good, D.A.; Parra-Olea, G.; Wake, D.B. Biodiversity of Costa Rican Salamanders: Implications of High Levels of Genetic Differentiation and Phylogeographic Structure for Species Formation. Proc. Natl. Acad. Sci. USA 2000, 97, 1640. [CrossRef]

37. Lips, K.R.; Green, D.E.; Papendick, R. Chytridiomycosis in Wild Frogs from Southern Costa Rica. J. Herpetol. 2003, 37, 215-218. [CrossRef]

38. Abarca, J.; Chaves, G.; García-Rodríguez, A.; Vargas, R. Reconsidering Extinction: Rediscovery of Incilius holdridgei (Anura: Bufonidae) in Costa Rica after 25 Years. Herpetol. Rev. 2010, 41, 150.

39. Chaves, G.; Zumbado-Ulate, H.; García-Rodríguez, A.; Gómez, E.; Vredenburg, V.T.; Ryan, M.J. Rediscovery of the Critically Endangered Streamside Frog, Craugastor taurus (Craugastoridae), in Costa Rica. Trop. Conserv. Sci. 2014, 7, 628-638. [CrossRef]

40. Zumbado-Ulate, H.; Willink, B. Craugastor ranoides. Geographic Distribution. Herpetol. Rev. 2011, $42,236$.

41. García-Rodríguez, A.; Arias, E.; Chaves, G. Multiple Lines of Evidence Support the Species Status of the Poorly Known Diasporus tigrillo and the Recently Described Diasporus citrinobapheus (Anura: Eleutherodactylidae). Neotropical Biodivers. 2016, 2, 59-68. [CrossRef]

42. Boza-Oviedo, E.; Rovito, S.M.; Chaves, G.; Garcia-Rodriguez, A.; Artavia, L.G.; Bolaños, F.; Wake, D.B. Salamanders from the Eastern Cordillera de Talamanca, Costa Rica, with Descriptions of Five New Species (Plethodontidae: Bolitoglossa, Nototriton, and Oedipina) and Natural History Notes from Recent Expeditions. Zootaxa 2012, 3309, 36-61. [CrossRef]

43. Zumbado-Ulate, H.; Nelson, K.N.; García-Rodríguez, A.; Chaves, G.; Arias, E.; Bolaños, F.; Whitfield, S.M.; Searle, C.L. Endemic Infection of Batrachochytrium dendrobatidis in Costa Rica: Implications for Amphibian Conservation at Regional and Species Level. Diversity 2019, 11, 129. [CrossRef]

44. García-Rodríguez, A.; Chaves, G.; Benavides-Varela, C.; Puschendorf, R. Where Are the Survivors? Tracking Relictual Populations of Endangered Frogs in Costa Rica. Divers. Distrib. 2012, 18, 204-212. [CrossRef]

45. Acosta-Chaves, V.J.; Madrigal-Elizondo, V.; Chaves, G.; Morera-Chacón, B.; Garcia-Rodriguez, A.; Bolaños, F. View of Shifts in the Diversity of an Amphibian Community from a Premontane Forest of San Ramón, Costa Rica. Rev. Biol. Trop. 2019, 67, 259-273. [CrossRef]

46. Acosta-Chaves, V.; Chaves, G.; Abarca, J.G.; García-Rodríguez, A.; Bolaños, F. A Checklist of the Amphibians and Reptiles of Río Macho Biological Station, Provincia de Cartago, Costa Rica. Check List 2015, 11, 1784. [CrossRef]

47. Rodríguez, J.; Chaves, G.; Neam, K.; Luedtke, J.; Carrillo, J.; Bolaños, F.; Matamoros, Y. Taller de Evaluación de Las Necesidades de Conservación de Anfibios-Arca de Los Anfibios y de La Lista Roja de La UICN: Un Esfuerzo Para La Segunda Evaluación Global de Anfibios; UICN SSC and CPSG Mesoamérica: San José, Costa Rica, 2019.

48. Wilson, L.D.; McCranie, J.R. The Conservation Status of the Herpetofauna of Honduras. Amphib. Reptile Conserv. 2004, 3, 6-33. [CrossRef] 
49. Chaves, G.; Bolaños, F.; Rodríguez, J.E.; Matamoros, Y. Actualización de Las Listas Rojas Nacionales de Costa Rica. Anfibios y Reptiles.; IUCN SSC and CBSG Mesoamerica: San José, Costa Rica, 2014.

50. International Union for Conservation of Nature (IUCN) The IUCN Red List of Threatened Species. Version 2019-1. Available online: https:/ / www.iucnredlist.org/en (accessed on 1 September 2021).

51. Sasa, M.; Chaves, G.; Porras, L.W. The Costa Rican herpetofauna: Conservation status and future perspectives. In Conservation of Mesoamerican Amphibians and Reptiles; Townsend, J.H., Johnson, J.D., Eds.; Eagle Mountain Press: Salt Lake City, UT, USA, 2010; pp. 510-603.

52. Hoffmann, H. Some Ecological Notes on Agalychnis annae (Anura: Hylidae). Brenesia 2006, 73-77.

53. IUCN SSC Amphibian Specialist Group. Agalychnis annae. Available online: https://www.iucnredlist.org/species/55288/158518 518 (accessed on 8 September 2021).

54. Arguedas-Porras, V. Parque Zoológico y Jardín Botánico Simón Bolívar El Hogar de La Rana Cafetalera Agalychnis Annae; Editorial Sobrevuelo: San José, Costa Rica, 2018.

55. Hertz, A.; Lotzkat, S.; Stadler, L.; Hamad, N.; Carrizo, A.; Köhler, G. Noteworthy Records of Amphibians from Western Panama. Herpetol. Rev. 2011, 42, 245-250.

56. Kubicki, B. Leaf-Frogs of Costa Rica; INBio: Heredia, Costa Rica, 2004.

57. De León, M.E.; Zumbado-Ulate, H.; García-Rodríguez, A.; Alvarado, G.; Sulaeman, H.; Bolaños, F.; Vredenburg, V.T. Batrachochytrium Dendrobatidis Infection in Amphibians Predates First Known Epizootic in Costa Rica. PLoS ONE 2019, 14, e0208969. [CrossRef]

58. Salazar Zuñiga, J.A.; Chaves Acuña, W.J.; Chaves, G.; Acuña, A.; Abarca Odio, J.I.; Lobon, J.; Gómez Méndez, E.; Gutiérrez Vannucchi, A.C.; Bolaños, F. The Most Frog-Diverse Place in Middle America, with Notes on Conservation Status of Six Threatened Species of Amphibians. Amphib. Reptile Conserv. 2019, 13, 304-322.

59. IUCN SSC Amphibian Specialist Group. Agalychnis Lemur. Available online: https://www.iucnredlist.org/species/55855/3033 153 (accessed on 8 September 2021).

60. Leenders, T. Amphibians of Costa Rica; Cornell University Press: New York, NY, USA, 2016.

61. IUCN SSC Amphibian Specialist Group. Duellmanohyla uranochroa. Available online: https://www.iucnredlist.org/species/5531 4/54345228 (accessed on 8 September 2021).

62. Savage, J.M.; Kubicki, B. A New Species of Fringe-Limb Frog, Genus Ecnomiohyla (Anura: Hylidae), from the Atlantic Slope of Costa Rica, Central America. Zootaxa 2010, 2719, 21-34. [CrossRef]

63. IUCN SSC Amphibian Specialist Group. Isthmohyla angustilineata. Available online: https://www.iucnredlist.org/species/55390/ 54345829 (accessed on 8 September 2021).

64. Chaves-Acuña, W.; Chaves, G.; Klank, J.; Arias, E.; Bolaños, F.; Shepack, A.; Leenders, T.; Cossel, J.; Faivovich, J. Recent Findings of Isthmohyla pictipes (Anura: Hylidae) in Costa Rica: Variation and Implications for Conservation. Zootaxa 2020, 4881, 499-514. [CrossRef]

65. IUCN SSC Amphibian Specialist Group. Isthmohyla pictipes. Available online: https://www.iucnredlist.org/species/55603/5436 2143 (accessed on 8 September 2021).

66. IUCN SSC Amphibian Specialist Group. Isthmohyla pseudopuma. Available online: https://www.iucnredlist.org/species/55616/ 54347154 (accessed on 8 September 2021).

67. IUCN SSC Amphibian Specialist Group. Isthmohyla rivularis. Available online: https://www.iucnredlist.org/species/55627/3031 396 (accessed on 8 September 2021).

68. Flemons, P.; Guralnick, R.; Krieger, J.; Ranipeta, A.; Neufeld, D. A Web-Based GIS Tool for Exploring the World's Biodiversity: The Global Biodiversity Information Facility Mapping and Analysis Portal Application (GBIF-MAPA). Ecol. Inform. 2007, 2, 49-60. [CrossRef]

69. Salazar, S. Redescubrimiento de La Rana Marsupial Gastrotheca Cornuta (Anura: Hemiphractidae) En Costa Rica. Brenesia 2015, 83-84, 81-82.

70. Hidalgo-Mora, E.; Valverde-Castillo, A.; Abarca, J.G. Range Extension of the Blue-Sided Leaf Frog, Agalychnis annae (Anura: Hylidae): Using Citizen Science across Suburban Areas in Costa Rica. Reptil. Amphib. 2021, 28, 264-267. [CrossRef]

71. Olsen, A.C.; Cossel JR, J.O. Observations of a Remnant Population of the Critically Endangered Hylid Frog Isthmohyla rivularis on the Monteverde Cloud Forest Preserve, Costa Rica. Herpetol. Rev. 2014, 45, 205-208.

72. Whitfield, S.M.; Alvarado, G.; Abarca, J.; Zumbado-Ulate, H.; Zuñiga, I.; Wainwright, M.; Kerby, J. Differential Patterns of Batrachochytrium dendrobatidis Infection in Relict Amphibian Populations Following Severe Disease-Associated Declines. Dis. Aquat. Organ. 2017, 126, 33-41. [CrossRef]

73. Barrio-Amorós, C.; Torres, H. Ecnomiohyla miliaria. Distribution in Pacific Costa Rica. Mesoamerican Herpetol. $2017,4,660-661$.

74. Zizka, A.; Silvestro, D.; Andermann, T.; Azevedo, J.; Ritter, C.D.; Edler, D.; Farooq, H.; Herdean, A.; Ariza, M.; Scharn, R.; et al. CoordinateCleaner: Automated Cleaning of Occurrence Records from Biological Collections. Methods Ecol. Evol. 2020, $10,744-751$.

75. Brown, J.L.; Carnaval, A.C. A Tale of Two Niches: Methods, Concepts, and Evolution. Front. Biogeogr. 2019, 11. [CrossRef]

76. Booth, T.H.; Nix, H.A.; Busby, J.R.; Hutchinson, M.F. BIOCLIM: The First Species Distribution Modelling Package, Its Early Applications and Relevance to Most Current MaxEnt Studies. Divers. Distrib. 2014, 20, 1-9. [CrossRef] 
77. Fick, S.E.; Hijmans, R.J. WorldClim 2: New 1-Km Spatial Resolution Climate Surfaces for Global Land Areas. Int. J. Climatol. 2017, 37, 4302-4315. [CrossRef]

78. Title, P.O.; Bemmels, J.B. ENVIREM: An Expanded Set of Bioclimatic and Topographic Variables Increases Flexibility and Improves Performance of Ecological Niche Modeling. Ecography 2018, 41, 291-307. [CrossRef]

79. Hijmans, R.J.; Van Etten, J.; Cheng, J.; Mattiuzzi, M.; Sumner, M.; Greenberg, J.A.; Lamigueiro, O.P.; Bevan, A.; Racine, E.B.; Shortridge, A. Package 'Raster'. R Package. 2015. Available online: https://cran.r-project.org/web/packages/raster/index.html (accessed on 1 September 2021).

80. Naimi, B. Usdm: Uncertainty Analysis for Species Distribution Models. R Package Version 1.1-15. 2015. Available online: https: / / cran.r-project.org/web/packages/usdm/index.html (accessed on 1 September 2021).

81. Ortiz-Malavasi, E. Atlas Digital Costa Rica. 2014. Available online: https: / / repositoriotec.tec.ac.cr $/$ handle $/ 2238 / 6749$ ?show=full (accessed on 1 September 2021).

82. Bland, L.M.; Keith, D.A.; Miller, R.M.; Murray, N.J.; Rodríguez, J.P. (Eds.) Guidelines for the Application of IUCN Red List of Ecosystems Categories and Criteria, Version 1.1; IUCN International Union for Conservation of Nature: Gland, Switzerland, 2017; ISBN 978-2-8317-1769-2.

83. Brooks, T.M.; Pimm, S.L.; Akçakaya, H.R.; Buchanan, G.M.; Butchart, S.H.M.; Foden, W.; Hilton-Taylor, C.; Hoffmann, M.; Jenkins, C.N.; Joppa, L.; et al. Measuring Terrestrial Area of Habitat (AOH) and Its Utility for the IUCN Red List. Trends Ecol. Evol. 2019, 34, 977-986. [CrossRef] [PubMed]

84. Phillips, S.J.; Dudík, M. Modeling of Species Distributions with Maxent: New Extensions and a Comprehensive Evaluation. Ecography 2008, 31, 161-175. [CrossRef]

85. Muscarella, R.; Galante, P.J.; Soley-Guardia, M.; Boria, R.A.; Kass, J.M.; Uriarte, M.; Anderson, R.P. ENMeval: An R Package for Conducting Spatially Independent Evaluations and Estimating Optimal Model Complexity for Maxent Ecological Niche Models. Methods Ecol. Evol. 2014, 5, 1198-1205. [CrossRef]

86. Phillips, S.J.; Anderson, R.P.; Dudík, M.; Schapire, R.E.; Blair, M.E. Opening the Black Box: An Open-Source Release of Maxent. Ecography 2017, 40, 887-893. [CrossRef]

87. Shcheglovitova, M.; Anderson, R.P. Estimating Optimal Complexity for Ecological Niche Models: A Jackknife Approach for Species with Small Sample Sizes. Ecol. Model. 2013, 269, 9-17. [CrossRef]

88. Radosavljevic, A.; Anderson, R.P. Making Better MAXENT Models of Species Distributions: Complexity, Overfitting and Evaluation. J. Biogeogr. 2014, 41, 629-643. [CrossRef]

89. Hijmans, R.J.; Phillips, S.; Leathwick, J.; Elith, J. Dismo: Species Distribution Modeling. R Package Version 1.3-5. 2021. Available online: https:/ / cran.r-project.org/web/packages/dismo/index.html (accessed on 1 September 2021).

90. Liu, C.; Newell, G.; White, M. On the Selection of Thresholds for Predicting Species Occurrence with Presence-Only Data. Ecol. Evol. 2016, 6, 337-348. [CrossRef] [PubMed]

91. Nilsen, E.B.; Pedersen, S.; Linnell, J.D.C. Can Minimum Convex Polygon Home Ranges Be Used to Draw Biologically Meaningful Conclusions? Ecol. Res. 2008, 23, 635-639. [CrossRef]

92. Nishida, K. Encounter with Hyla angustilineata Taylor, 1952 (Anura: Hylidae) in a Cloud Forest of Costa Rica. Brenesia 2006, 79-81.

93. Scheele, B.C.; Foster, C.N.; Hunter, D.A.; Lindenmayer, D.B.; Schmidt, B.R.; Heard, G.W. Living with the Enemy: Facilitating Amphibian Coexistence with Disease. Biol. Conserv. 2019, 236, 52-59. [CrossRef]

94. Puschendorf, R.; Hoskin, C.J.; Cashins, S.D.; McDonald, K.; Skerratt, L.F.; Vanderwal, J.; Alford, R.A. Environmental Refuge from Disease-Driven Amphibian Extinction. Conserv. Biol. 2011, 25, 956-964. [CrossRef] [PubMed]

95. Granados-Martínez, S.; Zumbado-Ulate, H.; Searle, C.L.; Oliveira, B.F.; García-Rodríguez, A. Niche Contraction of an Endangered Frog Species Driven by the Amphibian Chytrid Fungus. EcoHealth 2021, 18, 134-144. [CrossRef] [PubMed]

96. Christie, M.R.; Searle, C.L. Evolutionary Rescue in a Host-Pathogen System Results in Coexistence Not Clearance. Evol. Appl. 2018, 11, 681-693. [CrossRef] [PubMed]

97. DiRenzo, G.V.; Zipkin, E.F.; Grant, E.H.C.; Royle, J.A.; Longo, A.V.; Zamudio, K.R.; Lips, K.R. Eco-Evolutionary Rescue Promotes Host-Pathogen Coexistence. Ecol. Appl. 2018, 28, 1948-1962. [CrossRef]

98. Price, P.W.; Westoby, M.; Rice, B.; Atsatt, P.R.; Fritz, R.S.; Thompson, J.N.; Mobley, K. Parasite Mediation in Ecological Interactions. Annu. Rev. Ecol. Syst. 1986, 17, 487-505. [CrossRef]

99. Scheele, B.C.; Hunter, D.A.; Brannelly, L.A.; Skerratt, L.F.; Driscoll, D.A. Reservoir-Host Amplification of Disease Impact in an Endangered Amphibian. Conserv. Biol. 2017, 31, 592-600. [CrossRef]

100. Acosta-Chaves, V.J.; Cossel, J., Jr. Smilisca phaeota. Colonization. Mesoamerican Herpetol. 2016, 3, $713-715$.

101. Morera-Chacón, B.H.; Chaves-Acosta, V.J. Amphibians from the Cloud Forest of El Silencio de Los Ángeles, San Ramón de Alajuela, Costa Rica. Pensam. Actual 2019, 19, 190-204. [CrossRef]

102. Abarca, J.G. Cambios En La Estructura de La Comunidad de Anuros (Amphibia: Anura) En El Cerro Chompipe, Costa Rica. Cuad. Investig. UNED 2012, 4, 9-15.

103. Valencia-Aguilar, A.; Cortés-Gómez, A.M.; Ruiz-Agudelo, C.A. Ecosystem Services Provided by Amphibians and Reptiles in Neotropical Ecosystems. Int. J. Biodivers. Sci. Ecosyst. Serv. Manag. 2013, 9, 257-272. [CrossRef] 